\title{
DOŽIVLJAJ SAMOGA SEBE I OKOLINE KOD RODITELJA DJECE UREDNOG RAZVOJA I RODITELJA DJECE S RAZVOJNIM TEŠKOĆAMA
}

\author{
IVANA RAŠAN ${ }^{1}$, ŽELJKA CAR ${ }^{1}$, JASMINA IVŠAC PAVLIŠA ${ }^{2}$ \\ ${ }^{1}$ Sveučilište u Zagrebu, Fakultet elektrotehnike i računarstva, ${ }^{2}$ Sveučilište u Zagrebu, Edukacijsko-rehabilitacijski \\ fakultet, kontakt: ivana.rasan@fer.hr, zeljka.car@fer.hr, jasmina.ivsac.pavlisa@erf.hr
}

Primljeno: 26.1.2017.

Izvorni znanstveni rad

Prihvaćeno: 16.10.2017.

UDK: $159.922 .7-053.3 / .4$

Sažetak: Roditeljstvo djece s teškoćama donosi brojne izazove, a visoka razina stresa se povezuje s nedostatnom stručnom podrškom (Paster, Brandwein, Walsh, 2009). Nadalje, roditelji djece s razvojnim teškoćama često doživljavaju neuspjeh te svoje kompetencije u kontekstu roditeljstva nerijetko interpretiraju nerealno negativno (Kralj, 2012). S obzirom na oskudnost istraživačkih inicijativa na ovu temu, cilj rada je provjeriti postoje li razlike u samoprocjeni različitih životnih segmenata između roditelja djece s teškoćama i roditelja djece urednog razvoja. Istraživanje je provedeno tijekom projekta na kojem su se provodile aktivnosti osnaživanja roditelja djece s teškoćama i jačanja njihovih kapaciteta za bolji plasman na tržište rada. U istraživanju je sudjelovalo ukupno 60 roditelja - 30 roditelja koji imaju djecu s teškoćama i 30 roditelja djece urednog razvoja. Za potrebe istraživanja sastavljen je anketni upitnik u kojem je korištena skala Likertovog tipa od 1 do 5. S ciljem utvrđivanja razlika između navedenih skupina ispitanika korišten je neparametrijski test sume rangova (Mann-Whitney U test). Utvrđeno je da postoje razlike u samoprocjeni osobnog zadovoljstva $i$ vlastite uspješnosti u korist roditelja koji imaju djecu urednog razvoja, ali je isto tako utvrđeno da u ostalim segmentima njihove samoprocjene (kao što je npr. težnja za napretkom, pozitivan stav, zadovoljstvo razinom vlastitih postignuća/ciljeva, itd.) ne postoje značajne razlike između dvije navedene skupine. Dobiveni rezultati ukazuju na pozitivan stav prilikom suočavanja s različitim izazovnim životnim situacijama kojeg je moguće tumačiti kroz postojanje vlastite osobnosti pojedinca te nizom individualnih događaja koji ga kroz život određuju (Lacković-Grgin, 2011), a ne pripadnosti jednoj od skupina.

Ključne riječi: izazovno roditeljstvo, djeca s teškoćama, djeca urednog razvoja, roditelji djece s teškoćama, roditelji djece urednog razvoja, samoprocjena

\section{UVOD}

Današnje shvaćanje obitelji bitno se razlikuje od onog tradicionalnog. Niz društvenih promjena utječe na poimanje i funkcioniranje obitelji pa se tako mijenja i sam njezin koncept koji više nužno ne podrazumijeva strukturu oca, majke te bližih i daljih rođaka (Pećnik, 2008; Petani, 2012).

Suvremeno roditeljstvo donosi mnoge izazove koji posljedično mogu utjecati na daljnji osobni razvoj roditelja te njihovu percepciju sebe (Starc, 2014).

Sama evolucija pojedinca pod utjecajem je brojnih vanjskih čimbenika, ali i njegovog biološkog odgovora na zbivanja u okolini (Britvić, 2010). Tako postoji i niz čimbenika (psihološki, socijalni, biološki) koji utječu na motivaciju za roditelj- stvo, a kasnije igraju ključnu ulogu u tom životnom segmentu (Lacković-Grgin, 2011). Dosadašnje spoznaje ukazuju na to da se roditeljstvo odražava na psihološko zdravlje osobe kako u pozitivnom tako i u negativnom smislu (Smojver-Ažić, MartinacDorčić, 2010). Prema tome, jedna od značajnijih promjena za pojedinca jest upravo činjenica da postaje roditelj. Suvremeni svijet kojeg karakteriziraju česte promjene u svim životnim segmentima i koji se odlikuje složenošću i raznolikošću, pridaje roditeljstvu jednu od najodgovornijih funkcija $u$ okviru obitelji (Maleš, 1993). Roditeljska uloga podrazumijeva niz promjena koje mogu voditi do povećane razine stresa i napora koji se znatno povećavaju prilikom spoznaje kako djetetov razvoj ne teče uredno (Britvić, 2010; Smojver-Ažić, Martinac-Dorčić, 2010). Danas se smatra da otpri- 
like $10 \%$ djece ne slijedi urednu razvojnu krivulju te se njihovi roditelji od trenutka kada saznaju kako im se dijete razlikuje od svojih vršnjaka kontinuirano suočavaju s različitim izazovima (Ljubešić, Šimleša 2016; Seligman, Darling, 2007).

Roditelji djece s teškoćama izloženi su brojnim novim situacijama kao što su potraga za stručnom podrškom, povećani materijalni izdaci, nužnost stjecanja novih znanja i vještina vezanih za vrstu djetetove teškoće, organizacija vremena vezano za brigu oko djeteta, veća odsutnost s radnog mjesta, a ponekad i odricanje od vlastite karijere. Sve navedeno može utjecati na visoku razinu stresa $i$ promjene u ponašanju roditelja te kvalitetu života cijele obitelji (Lebedina-Manzoni, Novak, Jeđud, 2006; Popčević, Ivšac Pavliša, Šimleša, 2015). U mnogim zapadnim zemljama za roditelje djece s teškoćama je osiguran sustav podrške od strane različitih stručnjaka, dok je u Hrvatskoj takav oblik podrške još uvijek u začetku (Petani, 2012; Ljubešić, Šimleša, Bučar, 2015).

Dugogodišnja klinička iskustva prikupljena u Centru za rehabilitaciju Edukacijskorehabilitacijskog fakulteta (ERF) Sveučilišta u Zagrebu pokazuju da se roditelji djece s razvojnim teškoćama suočavaju s izazovima prilikom stvaranja i/ili održavanja radnog odnosa. Inozemna istraživanja ukazuju na trend čestih promjena poslova, skraćenog radnog vremena i odbijanja napredovanja (Home, 2002). Mogućnosti zaposlenja, poboljšanje kvalitete predškolskog odgoja i dostupnije korištenje dječjih vrtića (Pećnik, 2013) imali bi znatan pozitivan utjecaj na roditelje djece s teškoćama, ali i na roditelje djece urednog razvoja (Britvić, 2010; Ackerman, 1958).

Važno je napomenuti kako i roditelji djece urednog razvoja danas često osjećaju nesigurnost i anksioznost u svim segmentima odgoja djece. Roditelji su usmjereni na traženje savjeta od strane specijalista iz područja psihologije i medicine, dok su ih ranije tražili od starijih generacija - bake, djedovi i sl., (Pernar 2010). Javlja se roditeljski stres koji je omeđen nizom različitih psiholoških i fizioloških reakcija roditelja koje dolaze kao odgovor na tu situaciju te donose nove zahtjeve za pojedinca sada roditelja (Deater-Deckard, 2004). Stres isto tako može vrlo lako utjecati na samoprocjenu - koja podrazumijeva organizaciju iskustava individue te ideju o njoj samoj u svim životnim segmentima (Lebedina-Manzoni, Novak, Jeđud, 2006).

Kada se promatraju roditelji djece s teškoćama, istraživanja pokazuju kako su kod njih visoke razine stresa posljedica nedostatnog sustava podrške (Paster, Brandwein, Walsh, 2009).

Paster i suradnici (2009) su uspoređivali strategije suočavanja sa stresnim situacijama između roditelja djece s teškoćama i roditelja djece urednog razvoja. Utvrđeno je da roditelji djece s teškoćama koriste drugačije strategije suočavanja sa stresom nego li roditelji djece urednog razvoja. Nadalje, zaključuje se da bi pružanje odgovarajuće socijalne podrške za roditelje djece s teškoćama dovelo do smanjenja roditeljskog stresa i povećanja kvalitete života.

Temeljem navedenog i s obzirom na oskudnost istraživačkih inicijativa na ovu temu, željelo se provjeriti postoje li razlike u samoprocjeni između roditelja djece s teškoćama i roditelja djece urednog razvoja.

\section{RODITELJSTVO I ULOGA RODITELJA DANAS}

Kada se javila ideja o tome da su majka i otac jednako važni za razvoj djeteta, bez obzira na činjenicu da su uloge majke i oca gotovo potpuno različite, sve se više govori o terminu roditeljstvo (Pernar, 2010). Roditeljstvo se odnosi na niz procesa koji se sastoje od zadataka, uloga, pravila, komunikacije i međuljudskih odnosa koje roditelji ostvaruju u kontaktu sa svojim djetetom te se stoga roditeljstvo može definirati kao dinamičan i uzajamni socijalni proces (Klarin, 2006). Od roditelja se očekuje pružanje podrške djetetu u svim segmentima njegova razvoja - fizičkom, kognitivnom, socijalnom, emotivnom, moralnom, duhovnom, kulturnom, obrazovnom, seksualnom, itd. (Kušević, 2009). Danas, kada je prisutan sve veći odmak od tradicionalnih uloga majke i oca u kontekstu ranije jasne podijeljenosti, javlja se niz vanjskih utjecaja koji kroz svoje djelovanje u roditeljima mogu izazvati brojne značajnije promjene. One se mogu odraziti na razinu njihova zadovoljstva samima sobom i razinu zadovoljstva u odnosima s okolinom (Lacković-Grgin, 2011). To u konačnici može dovesti do promjene odnosa prema samome sebi, 
a posljedično tome i do promjene odnosa prema djetetu (Ackerman, 1958.). U kliničkom radu (Ljubešić, 2004) uočeno je kako suvremeni roditelji osjećaju veliku odgovornost kada je u pitanju odgoj djece, ali i prisutnost straha vezano za odgoj koji se kasnije može odraziti na djetetovu budućnost. Ista autorica navodi da su roditelji opterećeni nužnošću postizanja savršenstva u kontekstu roditeljstva, te se tako stvara osjećaj da sreća i budućnost njihova djeteta ovise isključivo o njihovim postupcima. $\mathrm{Na}$ putu ka ostvarenju često nerealnih vlastitih ciljeva te zbog straha da ne pogriješe, javlja se nesigurnost kod mnogih mladih roditelja. Današnji način života, koji podrazumijeva nužnost ostvarivanja niza zahtjeva i zadovoljenja brojnih očekivanja, dovodi do dodatnih opterećenja kako za roditelje tako i za djecu, a njihov negativni učinak odražava se na cijelu obitelj. Dolazi do prenaglašenog usmjeravanja energije na razna poučavanja, treniranja i educiranja djece čime izostaje blizak odnos roditelja i djeteta koji se postiže opuštenim zajedničkim druženjem, a upravo je isti od neprocjenjive važnosti za djetetov emocionalni i intelektualni razvoj (Brazelton, Greenspan, 2000). Već ranije spomenuta činjenica kako se danas roditelji sve manje oslanjaju na starije generacije te pomoć traže iz drugih izvora (stručnjaci, literatura, razni priručnici, internetski izvori, edukacije, stručna savjetovanja i sl.) također može utjecati na povećanje roditeljskog stresa.

Stoga je bitno osvijestiti kako roditeljstvo nije moguće odrediti kao isključivo pozitivno ili isključivo negativno iskustvo, već kao skup pozitivnih i negativnih doživljaja koji se mijenjaju u određenim razdobljima (Pernar,2010). Ono je određeno obilježjima kao što su osobnost oca i majke, socioekonomski status te dostupnost ljudi i institucija koje pružaju razne vrste podrške roditeljima (Pernar, 2010). Doživljaj roditeljstva ima važnu ulogu u određivanju „klime djetetova razvoja“, a također ima i snažan utjecaj na njegove razvojne rezultate (Čudina-Obradović i Obradović, 2006). Činjenica da su dvoje odraslih ljudi postali roditelji značajno mijenja njihovu svakodnevicu (vrste aktivnosti, raspored, prioritete i sl.) pa tako može doći i do promjena u njihovom doživljaju sebe $\mathrm{s}$ obzirom na novu životnu ulogu. Povećanje stresa može uzrokovati probleme u roditeljstvu kao što je neravnoteža u odnosima koja za posljedicu nerijetko ima kako negativan utjecaj na djetetov razvoj, tako i na samog roditelja (javlja se anksioznost, depresija i sl.) (Abidin, 1995). Prilikom promatranja roditeljskog stresa treba imati na umu postojanje privremenog stresa koji nije toliko opasan te kroničnog stresa koji za posljedicu može imati brojne negativne učinke na roditelja, ali i na cijelu obitelj (Kralj, 2012). Često dolazi do zanemarivanja činjenice kako neravnotežu u obitelji (koju može izazvati gubitak posla, bolest, smrt i sl.) nije uvijek moguće prebroditi u okviru same obitelji već se stvara potreba i za dodatnom podrškom (Britvić, 2010). Istraživanja pokazuju (Judge, 1998; Paster i sur., 2009) da je u kontekstu smanjenja negativnih učinaka stresa kod roditelja djece s teškoćama vrlo bitan čimbenik socijalna podrška, koja se odnosi na percipiranu pomoć pruženu od strane drugih grupa ili ljudi (Sarafino, 2002).

Sve navedeno ukazuje na to koliko je samopoimanje roditeljske uloge kao takve (Simon, 1992) ključno u kontekstu samog roditeljstva i koliko ono može utjecati na samoprocjenu te je upravo to $\mathrm{u}$ fokusu ovog istraživanja.

\section{CILJ RADA}

Cilj ovog istraživanja je provjeriti postoje li razlike između roditelja djece urednog razvoja $i$ roditelja djece s teškoćama u njihovoj samoprocjeni i doživljaju sebe kroz promatranje sljedećih segmenata: sklonost i težnja ka napretku, postizanje ciljeva, doživljaj odnosa s okolinom, poimanje sebe kao organizirane osobe, poimanje sebe kao tolerantne osobe, poimanje važnosti vremena koje se odvaja za obitelj, doživljaj sebe kao pozitivne osobe, doživljaj sebe kao zadovoljne osobe i doživljaj vlastitog uspjeha. Subjektivni doživljaj roditeljstva stvara značajnu promjenu cjelokupnog identiteta roditelja (Leutar i Oršulić, 2015) zbog čega se postavlja pitanje hoće li dodatni izazovi s kojima se suočavaju roditelji djece s razvojnim teškoćama utjecati na njihovu samoprocjenu. Ujedno se željelo provjeriti jesu li eventualne razlike u samoprocjeni vezane uz specifične okolnosti u kojima su se članovi obje skupine kao roditelji našli ili su razlike vezane isključivo za pojedinca kao takvog i njegov doživljaj sebe u ulozi roditelja. 


\section{PRETPOSTAVKE ISTRAŽIVANJA}

Postavljene su sljedeće pretpostavke: Pretpostavka 1: Ne postoji značajna razlika između roditelja djece urednog razvoja i roditelja djece s teškoćama vezano za njihove sklonosti prema stjecanju novih znanja i vještina; Pretpostavka 2: Ne postoji značajna razlika u razini samoprocjene zadovoljstva postignutim osobnim ciljevima između roditelja djece urednog razvoja i roditelja djece s teškoćama; Pretpostavka 3: Ne postoji značajna razlika u vlastitom doživljaju dobrih odnosa s okolinom između roditelja djece urednog razvoja i onih koji imaju djecu s teškoćama; Pretpostavka 4: Ne postoji značajna razlika u razini zadovoljstva vezano za način na koji se okolina odnosi prema roditeljima djece urednog razvoja u odnosu na roditelje djece s teškoćama; Pretpostavka 5: Ne postoji značajna razlika u samoprocjeni vlastitih organizacijskih sposobnosti između roditelja djece urednog razvoja i roditelja djece s teškoćama; Pretpostavka 6: Ne postoji značajna razlika u samoprocjeni sebe kao tolerantne osobe u interakciji s okolinom između roditelja djece urednog razvoja i roditelja djece s teškoćama; Pretpostavka 7: Ne postoji značajna razlika između roditelja djece urednog razvoja i roditelja djece s teškoćama u njihovom poimanju važnosti vremena koje će provoditi sa svojom obitelji1' Pretpostavka 8: Ne postoji značajna razlika u samoprocjeni sebe kao osobe koja ima pozitivan stav prema životu između roditelja djece urednog razvoja i roditelja djece s teškoćama; Pretpostavka 9: Ne postoji značajna razlika u samoprocjeni životnog zadovoljstva između roditelja djece urednog razvoja i roditelja djece s teškoćama; Pretpostavka 10: Ne postoji značajna razlika u samoprocjeni vlastite uspješnosti između roditelja djece urednog razvoja i roditelja djece s teškoćama.

\section{METODE ISTRAŽIVANJA}

\section{Uzorak ispitanika}

U istraživanju je sudjelovao prigodan uzorak roditelja $(\mathrm{N}=60)$. Roditelji su podijeljeni u dvije skupine - skupina roditelja djece s teškoćama u razvoju $(\mathrm{N}=30)$ i skupina roditelja djece urednog razvoja $(\mathrm{N}=30)$. Roditelji su majke u dobi između
30 i 45 godina starosti, dok su djeca u dobi između 5 i 12 godina. Djeca s teškoćama imaju dijagnozu poremećaja iz spektra autizma ili općih razvojnih teškoća zbog čega zahtijevaju visoki stupanj stručne podrške (Not, 2008).

Roditelji djece s teškoćama koji su sudjelovali $\mathrm{u}$ istraživanju su s područja Zagrebačke i Brodskoposavske županije. Anketirani roditelji djece urednog razvoja su s područja Zagrebačke i Požeškoslavonske županije.

Ograničenja uzorka: U ovom istraživanju sudjelovali su roditelji djece s teškoćama koji su uglavnom nezaposleni ili su zaposleni, ali nisu radno aktivni jer koriste pravo na produženi rodiljni dopust. Drugu skupinu čine roditelji djece urednog razvoja koji su zaposleni te ih ta činjenica stavlja u bolji položaj u odnosu na prvu skupinu.

\section{Provedba istraživanja}

Roditelji djece s teškoćama anketirani su zbog sudjelovanja u projektu MULTI-SKLAD ${ }^{2}$, dok je 30 roditelja djece urednog razvoja dohvaćeno iz baze podataka roditelja stvorene tijekom prethodnog projekta ${ }^{3}$. Prilikom provedbe istraživanja osigurana je anonimnost. Svih 60 roditelja je odgovorilo na sva postavljena pitanja. Dio roditelja je anketne upitnike ispunio tijekom prvog susreta sa stručnjacima zaposlenima na projektu, dok je dio roditelja iste ispunio elektroničkim putem (upitnik je bio dostupan u obliku Google obrazaca). Nakon istraživanja uslijedilo je kodiranje dobivenih podataka.

\section{Mjerni instrument}

Za potrebe ovog istraživanja sastavljen je anketni upitnik u kojem je korištena skala Likertovog tipa od 1 do 5 ( 1 = uopće se ne slažem, 2 = uglavnom se ne slažem, $3=$ niti se slažem, niti se ne slažem, 4 = uglavnom se slažem, 5 = slažem se u potpunosti). Anketni upitnik je sastavljen od 34 čestice. Njihov redoslijed je unakrsno postavljen u svrhu dobivanja što iskrenijih odgovora i izbjegavanja uljepšavanja vlastitih doživljaja tijekom samoprocjene (Pap, 2007; Lebedina-Manzoni, Novak, Jeđud, 2006)

1 Obje skupine smatraju kako je važno provoditi vrijeme s obitelji.

2 http://multisklad.ict-aac.hr/

3 http://www.ict-aac.hr/index.php/hr/ 
do kojih može doći u okviru popunjavanja ovakve vrste upitnika. Oblikovane 34 čestice su koncipirane tako da ih je kasnije moguće povezati u segmente koji su vezani za 10 životnih područja prema postavljenim pretpostavkama. Upitnikom se želi provjeriti doživljaj samoga sebe u ulozi roditelja te kako taj doživljaj utječe na njihovu samoprocjenu u kontekstu osobnog djelovanja kao pojedinca i djelovanja u odnosima s okolinom (obitelj uža i šira, prijatelji, šira okolina i sl.). Radionice u kojima su sudjelovali roditelji djece s teškoćama su predviđale primjenu geštalt pristupa koji se koristi u individualnom ili timskom radu u svrhu postizanja razvoja i napretka te se najčešće vezuje uz „coaching“ (Čanić, 2013). Na oblikovanje čestica je utjecala geštalt teorija koja „naglašava cjelovitost osobe kao subjekta tijela, uma i duše u socijalnom i ekološkom okruženju s kojima je nerazdvojno povezana“ (Žic i sur., 1997). Upitnikom su obuhvaćeni svi životni segmenti prema kojima je oblikovan sadržaj edukativnih radionica u okviru projekta MULTI-SKLAD. Čestice su grupirane tako da je moguće promatrati samoprocjenu zadovoljstva i pozitivnog stava kroz usmjerenost na: zadovoljstvo postizanjem vlastitih ciljeva, opći doživljaj sebe kao zadovoljne osobe, doživljaj sebe kao osobe koja ima pozitivan pogled na životne okolnosti, osobe koja je zadovoljna s načinom na koji se okolina odnosi prema njoj te procjenom sebe kao uspješne osobe. (Npr. Osoba sam koja postiže svoje ciljeve.; Zadovoljna sam osoba.; Osoba sam koja je zadovoljna svojim fizičkim izgledom.; Pozitivna sam osoba.; Zadovoljan/ na sam načinom na koji se drugi odnose prema meni.; itd.). Promatrano je u kojoj mjeri ispitanici procjenjuju svoju težnju određenom ponašanju -stjecanju novih znanja i vještina, organizaciji, toleranciji, odvajanju vremena za obitelj. (Npr. Sklon/a sam stjecanju novih znanja i vještina.; Osoba sam koja teži napretku.; Organizirana sam osoba.; Sve uvijek moram dobro isplanirati.; Znam organizirati svoje vrijeme.; Tolerantna sam osoba.; Važno mi je imati vremena za svoju obitelj.; itd.). Promatrao se i njihov doživljaj interakcije s bližom i daljom okolinom. (Npr. Imam jako dobar odnos sa svojim prijateljima.;

4 SPSS Statistics, http://www.ibm.com/analytics/us/en/technology/spss/
Imam jako dobar odnos s članovima svoje uže obitelji.; Imam jako dobar odnos s članovima svoje šire obitelji., itd.).

\section{Metode obrade podataka}

Prikupljeni podaci unutar ovog istraživanja su obrađeni u programskom paketu SPSS Statistics ${ }^{4}$.

Normalnost distribucija varijabli provjerena je Shapiro-Wilk testom te je utvrđeno da distribucije varijabli odstupaju od očekivane normalne distribucije. Korišten je neparametrijski test sume rangova (Mann-Whitney U test) s ciljem utvrđivanja razlika između dvije skupine ispitanika. Testiranjem je računata suma rangova svakog uzorka temeljem koje su se uspoređivale dvije skupine u svrhu utvrđivanja (ne)postojanja značajne statističke razlike.

\section{REZULTATI I RASPRAVA}

\section{Razlike između roditelja djece urednog razvoja i roditelja djece $s$ teškoćama $s$ obzirom na njihove sklonosti prema stjecanju novih znanja i vještina}

Pretpostavlja se kako obje skupine roditelja teže ka stjecanju novih znanja i vještina, odnosno da ne postoje značajne razlike kada se radi o njihovim sklonostima prema stjecanju novih znanja i vještina. Mann-Whitney U test je pokazao da nema statistički značajne razlike u kontekstu povećanja zadovoljstva zbog stjecanja novih znanja i vještina između skupine roditelja djece urednog razvoja i skupine roditelja djece $\mathrm{s}$ teškoćama, $U=440.5$, $\mathrm{z}=-, 178$.

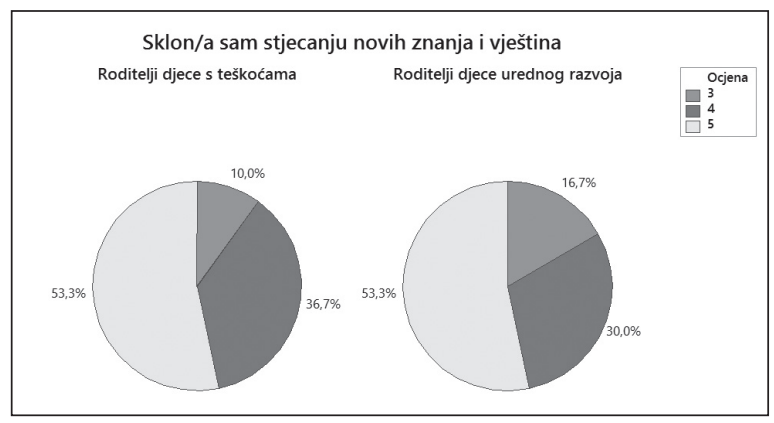

Slika 1. Sklonost roditelja ka stjecanju novih znanja $i$ vještina 
Tablica 1. Rangovi subjektivnih ocjena po skupinama za pretpostavku 1

\begin{tabular}{|l|l|c|c|c|}
\hline & Skupina & N & Prosjek ranga & Suma ranga \\
\hline \multirow{2}{*}{$\begin{array}{l}\text { Sklonost stjecanju novih znanja i } \\
\text { vještina }\end{array}$} & Roditelji djece s teškoćama & 30 & 30,97 & 929,00 \\
\cline { 2 - 5 } & Roditelji djece urednog razvoja & 30 & 30,03 & 901,00 \\
\hline \multirow{2}{*}{ Težnja napretku } & Roditelji djece s teškoćama & 30 & 29,63 & 889,00 \\
\cline { 2 - 5 } & Roditelji djece urednog razvoja & 30 & 31,37 & 941,00 \\
\hline $\begin{array}{l}\text { Povećano zadovoljstvo zbog } \\
\text { stjecanja novih znanja i vještina }\end{array}$ & Roditelji djece s teškoćama & 30 & 30,82 & 924,50 \\
\cline { 2 - 5 } & Roditelji djece urednog razvoja & 30 & 30,18 & 905,50 \\
\hline
\end{tabular}

Tablica 2. Mann-Whitney U testovi za pretpostavku 1

\begin{tabular}{|l|c|c|c|}
\hline & $\begin{array}{c}\text { Sklonost stjecanju novih } \\
\text { znanja i vještina }\end{array}$ & Težnja napretku & $\begin{array}{c}\text { Povećano zadovoljstvo zbog } \\
\text { stjecanja novih znanja i vještina }\end{array}$ \\
\hline Mann-Whitney U & 436,000 & 424,000 & 440,500 \\
\hline Wilcoxon W & 901,000 & 889,000 & 905,500 \\
\hline Z &,- 230 &,- 428 &,- 178 \\
\hline Egz. Sig. (dvostrani test) &, 845 &, 736 &, 952 \\
\hline Egz. Sig. (jednostrani test) &, 422 &, 368 &, 476 \\
\hline
\end{tabular}

Razlika između skupina također nije utvrđena ni kada je riječ o razini sklonosti stjecanja novih znanja i vještina $(U=436,000, z=-, 230)$ i težnji ka napretku (U=424,000, $z=-, 428)$.

Ukupno $90 \%$ roditelja djece s teškoćama odgovorilo je kako se uglavnom ili u potpunosti slažu s tvrdnjom da su skloni stjecanju novih znanja i vje-

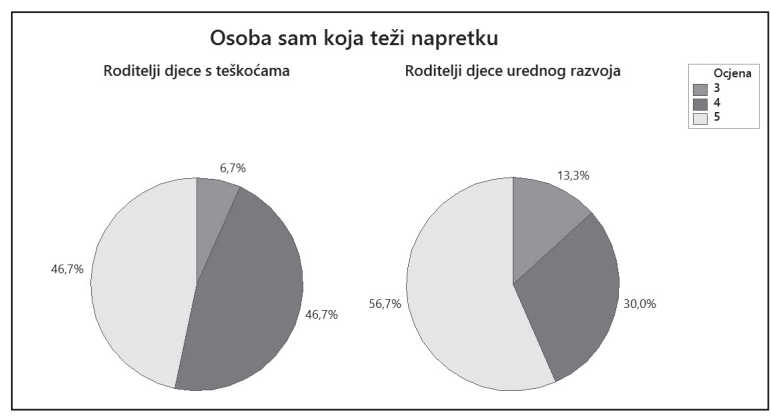

Slika 2. Sklonost roditelja napretku

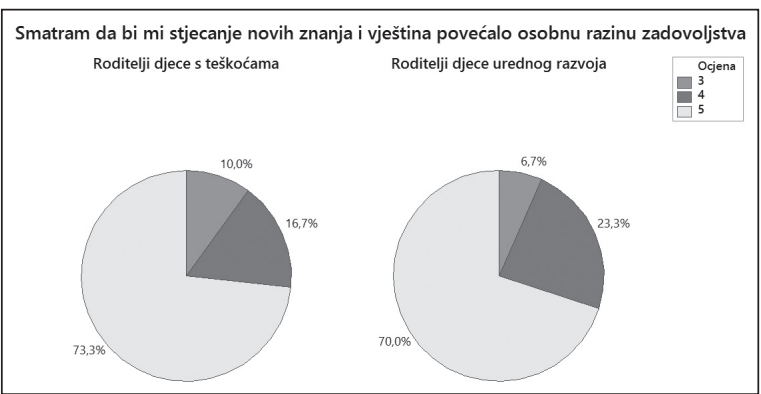

Slika 3. Odnos roditelja prema stjecanju novih znanja $i$ vještina ština, a isto je slučaj i kod $83,30 \%$ roditelja djece urednog razvoja. Obje skupine roditelja procjenjuju kako teže napretku, točnije $93,40 \%$ roditelja djece s teškoćama i $86,7 \%$ roditelja djece urednog razvoja. Iako prisutnost djeteta, odnosno samo roditeljstvo kao takvo izaziva snažne pozitivne, ali i negativne osjećaje u kontekstu promjena mišljenja, osjećaja, ponašanja (Čudina-Obradović i Obradović, 2003), iz navedenih odgovora je moguće zaključiti kako obje skupine roditelja u jednakoj mjeri teže napretku i raznim oblicima vlastitog ostvarenja.

Obje skupine se u gotovo jednakom omjeru $(73,30 \%$ roditelja djece s teškoćama i $70 \%$ roditelja djece urednog razvoja) slažu s tim da bi im stjecanje novih znanja i vještina povećalo osobnu razinu zadovoljstva. Miljković i Rijavec (2009) ističu kako sve više istraživanja dokazuje da pozitivne emocije znatno olakšavaju proces čovjekova funkcioniranja. Prema tome moguće je zaključiti kako stjecanje novih znanja i vještina stvara pozitivne emocije kod obje skupine roditelja, a time se povećava i njihova osobna razina zadovoljstva.

\section{Razlike između roditelja djece urednog razvoja i roditelja djece $s$ teškoćama $u$ samoprocjeni zadovoljstva postignutim osobnim ciljevima}

Pretpostavlja se da ne postoji značajna razlika u razini samoprocjene zadovoljstva postignutim 
Ivana Rašan, Željka Car, Jasmina Ivšac Pavliša: Doživljaj samoga sebe i okoline kod roditelja djece urednog razvoja i roditelja djece...

Tablica 3. Rangovi subjektivnih ocjena po skupinama za pretpostavku 2

\begin{tabular}{|l|l|c|c|c|}
\hline & Skupina & N & Prosjek ranga & Suma ranga \\
\hline \multirow{2}{*}{$\begin{array}{l}\text { Postizanje ciljeva vlastitim } \\
\text { resursima/snagama }\end{array}$} & Roditelji djece s teškoćama & 30 & 26,40 & 792,00 \\
\cline { 2 - 5 } & Roditelji djece urednog razvoja & 30 & 34,60 & 1038,00 \\
\hline \multirow{2}{*}{ Visoka razina vlastitih postignuća } & Roditelji djece s teškoćama & 30 & 27,05 & 811,50 \\
\cline { 2 - 5 } & Roditelji djece urednog razvoja & 30 & 33,95 & 1018,50 \\
\hline \multirow{2}{*}{ Postizanje ciljeva } & Roditelji djece s teškoćama & 30 & 27,73 & 832,00 \\
\cline { 2 - 5 } & Roditelji djece urednog razvoja & 30 & 33,27 & 998,00 \\
\hline
\end{tabular}

Tablica 4. Mann-Whitney U testovi za pretpostavku 2

\begin{tabular}{|l|c|c|c|}
\hline & $\begin{array}{c}\text { Postizanje vlastitim } \\
\text { resursima/snagama }\end{array}$ & $\begin{array}{c}\text { Visoka razina vlastitih } \\
\text { postignuća }\end{array}$ & Postizanje ciljeva \\
\hline Mann-Whitney U & 327,000 & 346,500 & 367,000 \\
\hline Wilcoxon W & 792,000 & 811,500 & 832,000 \\
\hline Z & $-1,925$ & $-1,619$ & $-1,357$ \\
\hline Egz. Sig. (dvostrani test) &, 049 &, 111 &, 192 \\
\hline Egz. Sig. (jednostrani test) &, 025 &, 056 &, 096 \\
\hline
\end{tabular}

osobnim ciljevima između roditelja djece urednog razvoja i roditelja djece s teškoćama. MannWhitney U test je pokazao da nema statistički značajne razlike, $U=367,000, z=-1,357$. Roditelji iz obje skupine procjenjuju da su osobe koje uglavnom ili u potpunosti postižu svoje ciljeve. Također, obje skupine uglavnom ili u potpunosti procjenjuju da su postigle puno u životu, točnije to smatra $50 \%$ roditelja djece s teškoćama i 70\% roditelja djece urednog razvoja.

No kada se radi o postizanju ciljeva vlastitim snagama, test je pokazao statistički značajnu razliku, $\mathrm{U}=327,000, \mathrm{z}=-1,925, \mathrm{p}<0,05$. Ukupno $80 \%$ roditelja djece urednog razvoja uglavnom ili u potpunosti procjenjuje da većinu toga u životu mogu postići vlastitim snagama, dok tako misli samo $50 \%$ roditelja djece s teškoćama. Razlika bi mogla biti povezana s činjenicom da se roditelji djece s teškoćama u određenim životnim segmentima nalaze $u$ izazovnijim i stresnijim situacijama u kojima im je potrebna dodatna podrška, a to potvrđuju i ranije spomenuta istraživanja (Paster, 2009). Milić Babić (2012) ističu kako brojna istraživanja (Antshel i Joseph, 2006; Waisbern, 2004) kao prediktore roditeljskog stresa navode zdravstveno stanje i vrstu teškoće djeteta. Autori također ističu kako istraživanja ukazuju na to da roditelji djece s teškoćama često puta imaju više stresnih životnih događaja koji ih kao roditelje mogu dovesti do raznih negativnih implikacija. Podrška koja je u tim situacijama roditeljima potrebna se ne svodi samo na podršku od strane bliže obitelji već i na formalnu i neformalnu podršku okoline (Milić Babić, 2012; Čudina-Obradović i Obradović, 2003).

\section{Razlike u doživljaju odnosa s okolinom između roditelja djece urednog razvoja i roditelja djece s teškoćama}

Primjenom Mann-Whitney U testa je potvrđeno da ne postoje značajne razlike u vlastitom doživljaju dobrih odnosa s okolinom između ove dvije skupine roditelja. Test je pokazao da nema statistički značajne razlike u samoprocjeni kvalitete odnosa s okolinom između roditelja djece urednog razvoja i roditelja koji imaju djecu s teškoćama vezano za sljedeće: odnosi s prijateljima ( $U=364,000$, $\mathrm{z}=-1,392$ ), odnosi s članovima njihove uže obitelji $(\mathrm{U}=405,500, \mathrm{z}=-, 729)$ i odnosi s članovima njihove šire obitelji $(U=416,000, z=-, 530)$. Obje skupine se uglavnom ili u potpunosti slažu s tvrdnjom da imaju dobre odnose s prijateljima i članovima svoje uže i šire obitelji.

Zanimljivo je kako u obje skupine postoji jedna osoba koja je odgovorila da ima loš odnos s članovima svoje uže obitelji, ali kod obje skupine niti jedna osoba nije odgovorila da ima loš odnos s članovima svoje šire obitelji. Bitno je istaknuti kako je jedan od najdominantnijih čimbenika koji utječu na samoprocjenu svake osobe upravo obi- 
Tablica 5. Rangovi subjektivnih ocjena po skupinama za pretpostavku 3

\begin{tabular}{|c|c|c|c|c|}
\hline & Skupina & $\mathbf{N}$ & Prosjek ranga & Suma ranga \\
\hline \multirow[t]{2}{*}{ Jako dobar odnos s prijateljima } & Roditelji djece s teškoćama & 30 & 27,63 & 829,00 \\
\hline & Roditelji djece urednog razvoja & 30 & 33,37 & 1001,00 \\
\hline \multirow{2}{*}{$\begin{array}{l}\text { Jako dobar odnos s članovima uže } \\
\text { obitelji }\end{array}$} & Roditelji djece s teškoćama & 30 & 29,02 & 870,50 \\
\hline & Roditelji djece urednog razvoja & 30 & 31,98 & 959,50 \\
\hline \multirow{2}{*}{$\begin{array}{l}\text { Jako dobar odnos s članovima šire } \\
\text { obitelji }\end{array}$} & Roditelji djece s teškoćama & 30 & 31,63 & 949,00 \\
\hline & Roditelji djece urednog razvoja & 30 & 29,37 & 881,00 \\
\hline
\end{tabular}

Tablica 6. Mann-Whitney U testovi za pretpostavku 3

\begin{tabular}{|l|c|c|c|}
\hline & $\begin{array}{c}\text { Jako dobar odnos s } \\
\text { prijateljima }\end{array}$ & $\begin{array}{c}\text { Jako dobar odnos s } \\
\text { članovima uže obitelji }\end{array}$ & $\begin{array}{c}\text { Jako dobar odnos s članovima } \\
\text { šire obitelji }\end{array}$ \\
\hline Mann-Whitney U & 364,000 & 405,500 & 416,000 \\
\hline Wilcoxon W & 829,000 & 870,500 & 881,000 \\
\hline Z & $-1,392$ &,- 729 &,- 530 \\
\hline Egz. Sig. (dvostrani test) &, 187 &, 502 &, 633 \\
\hline Egz. Sig. (jednostrani test) &, 093 &, 251 &, 317 \\
\hline
\end{tabular}

telj (Lebedina-Manzoni, Novak, Jeđud, 2006) te stoga ovi rezultati mogu biti promatrani kao iznimno pozitivni.

\section{Razlike u razini zadovoljstva u odnosima okoline prema roditeljima}

Promatrano je na koji način roditelji iz obje skupine doživljavaju odnose s okolinom te se željelo provjeriti postoji li razlika u razini zadovoljstva između roditelja djece urednog razvoja i rodite-

Tablica 7. Rangovi subjektivnih ocjena po skupinama za pretpostavku 4

\begin{tabular}{|l|l|c|c|c|}
\hline & Skupina & N & $\begin{array}{c}\text { Prosjek } \\
\text { ranga }\end{array}$ & $\begin{array}{c}\text { Suma } \\
\text { ranga }\end{array}$ \\
\hline $\begin{array}{l}\text { Zadovoljstvo } \\
\text { odnosom } \\
\text { okoline } \\
\text { prema } \\
\text { roditeljima }\end{array}$ & $\begin{array}{l}\text { Roditelji djece s } \\
\text { teškoćama }\end{array}$ & 30 & 27,57 & 827,00 \\
\cline { 2 - 5 } & $\begin{array}{l}\text { Roditelji djece } \\
\text { urednog razvoja }\end{array}$ & 30 & 33,43 & 1003,00 \\
\hline
\end{tabular}

Tablica 8. Mann-Whitney U testovi za pretpostavku 4

\begin{tabular}{|l|c|}
\hline & $\begin{array}{c}\text { Zadovoljstvo odnosom okoline } \\
\text { prema roditeljima }\end{array}$ \\
\hline Mann-Whitney U & 362,000 \\
\hline Wilcoxon W & 827,000 \\
\hline $\mathbf{Z}$ & $-1,403$ \\
\hline $\begin{array}{l}\text { Egz. Sig. } \\
\text { (dvostrani test) }\end{array}$ &, 154 \\
\hline $\begin{array}{l}\text { Egz. Sig. } \\
\text { (jednostrani test) }\end{array}$ &, 077 \\
\hline
\end{tabular}

lja djece s teškoćama vezano za način na koji se okolina odnosi prema njima. Kada je riječ o razini zadovoljstva odnosa okoline prema ove dvije skupine roditelja, Mann-Whitney U test pokazuje da ne postoji statistički značajna razlika, $U=362,000$, $\mathrm{z}=-1,403$.

Roditelji djece urednog razvoja su u 86,7\% slučajeva uglavnom zadovoljni s načinom na koji se drugi odnose prema njima, a kod roditelja djece $\mathrm{s}$ teškoćama je isto izraženo u $73,4 \%$ slučajeva.

Kako se u suvremenom pristupu stavlja sve veći naglasak na okolinu jer ona utječe na dijete u puno većoj mjeri od same teškoće (Brazelton, Greenspan, 2000; Igrić, Wagner, Cvitković, 2012), ovi rezultati mogu ukazati na postojanje kvalitetne podloge za inkluzivno društvo.

\section{Razlike u samoprocjeni organizacijskih sposobnosti između roditelja djece urednog razvoja i roditelja djece $s$ teškoćama}

Prikupljeni podaci pokazuju da 43,3\% roditelja djece s teškoćama sebe procjenjuje kao uglavnom organizirane osobe, dok je to kod roditelja djece urednog razvoja izraženo u 46,7\% slučajeva. Ovakvi odgovori poklapaju se i sa sistemskom teorijom koja obitelj definira kao složeni sustav (Minuchin, 1974), a svaki sustav definiran je određenim organizacijskim ulogama kako bi mogao funkcionirati. 
Ivana Rašan, Željka Car, Jasmina Ivšac Pavliša: Doživljaj samoga sebe i okoline kod roditelja djece urednog razvoja i roditelja djece...

Tablica 9. Rangovi subjektivnih ocjena po skupinama za pretpostavku 5

\begin{tabular}{|l|l|c|c|c|}
\hline & Skupina & N & Prosjek ranga & Suma ranga \\
\hline \multirow{2}{*}{ Organizacija vremena } & Roditelji djece s teškoćama & 30 & 32,48 & 974,50 \\
\cline { 2 - 5 } & Roditelji djece urednog razvoja & 30 & 28,52 & 855,50 \\
\hline \multirow{2}{*}{ Organizirana osoba } & Roditelji djece s teškoćama & 30 & 28,63 & 859,00 \\
\cline { 2 - 5 } & Roditelji djece urednog razvoja & 30 & 32,37 & 971,00 \\
\hline \multirow{2}{*}{ Dobro isplanirano vrijeme } & Roditelji djece s teškoćama & 30 & 29,75 & 892,50 \\
\cline { 2 - 5 } & Roditelji djece urednog razvoja & 30 & 31,25 & 937,50 \\
\hline \multirow{2}{*}{ Dobro organizirane aktivnosti } & Roditelji djece s teškoćama & 30 & 33,43 & 1003,00 \\
\cline { 2 - 5 } & Roditelji djece urednog razvoja & 30 & 27,57 & 827,00 \\
\hline
\end{tabular}

Tablica 10. Mann-Whitney U testovi za pretpostavku 5

\begin{tabular}{|l|c|c|c|c|}
\hline & $\begin{array}{c}\text { Organizacija } \\
\text { vremena }\end{array}$ & Organizirana osoba & $\begin{array}{c}\text { Dobro isplanirano } \\
\text { vrijeme }\end{array}$ & $\begin{array}{c}\text { Dobro organizirane } \\
\text { aktivnosti }\end{array}$ \\
\hline Mann-Whitney U & 390,500 & 394,000 & 427,500 & 362,000 \\
\hline Wilcoxon W & 855,500 & 859,000 & 892,500 & 827,000 \\
\hline Z &,- 936 &,- 886 &,- 353 & $-1,435$ \\
\hline Egz. Sig. (dvostrani test) &, 343 &, 389 &, 724 &, 175 \\
\hline Egz. Sig. (jednostrani test) &, 172 &, 194 &, 362 &, 087 \\
\hline
\end{tabular}

Obje skupine roditelja se u jednakom postotku (70\%) slažu s tvrdnjom kako uglavnom ili u potpunosti znaju organizirati svoje vrijeme. Također se u jednakom omjeru slažu (43,3\%) da uglavnom sve aktivnosti uvijek moraju dobro isplanirati, s tim da je roditeljima djece s teškoćama u $56,7 \%$ slučajeva dosta važno da aktivnosti u kojima sudjeluju budu dobro organizirane, a kod roditelja djece urednog razvoja to je zabilježeno u 50\% slučajeva.

Rezultati pokazuju kako ne postoji značajna razlika u samoprocjeni sebe kao organizirane osobe kod ove dvije skupine. Mann-Whitney U testovi su pokazali da nema statistički značajne razlike između ove dvije skupine roditelja kada je u pitanju njihov odnos prema organizaciji vremena $(\mathrm{U}=390,5$, $\mathrm{z}=-, 936)$, u samoprocjeni vlastite organiziranosti $(\mathrm{U}=394, \mathrm{z}=-, 886)$, težnji ka dobro isplaniranom vremenu ( $U=427,500, z=-, 353)$ i težnji ka dobro isplaniranim aktivnostima $(U=362,000, z=-1,435)$.

\section{Razlike u samoprocjeni razine tolerancije u odnosima s okolinom između roditelja djece urednog razvoja i roditelja djece s teškoćama}

Promatrana je samoprocjena razine tolerancije između dvije skupine roditelja. Primjena MannWhitney $U$ testa $(U=407,000, z=-, 715)$ pokazala je da ne postoje značajne statističke razlike u razini samoprocjene tolerancije između dvije skupine roditelja.
Roditelji djece s teškoćama sebe u 93,3\% slučajeva procjenjuju tolerantnim osobama, dok je to kod roditelja djece urednog razvoja prisutno u $80 \%$ slučajeva.

Iz dobivenih rezultata visokih vrijednosti, može se pretpostaviti kako su roditelji koji su sudjelovali u istraživanju odrastali kao ravnopravni članovi obitelji te nisu bili izloženi odnosu roditelj-nadređeni - dijete-podređeni kojeg karakterizira autoritarni stil roditeljstva (Pernar, 2010), već su kroz

Tablica 11. Rangovi subjektivnih ocjena po skupinama za pretpostavku 6

\begin{tabular}{|l|l|c|c|c|}
\hline & Skupina & N & $\begin{array}{c}\text { Prosjek } \\
\text { ranga }\end{array}$ & $\begin{array}{c}\text { Suma } \\
\text { ranga }\end{array}$ \\
\hline $\begin{array}{l}\text { Tolerantna } \\
\text { osoba }\end{array}$ & $\begin{array}{l}\text { Roditelji djece s } \\
\text { teškoćama }\end{array}$ & 30 & 31,93 & 958,00 \\
\cline { 2 - 5 } & $\begin{array}{l}\text { Roditelji djece } \\
\text { urednog razvoja }\end{array}$ & 30 & 29,07 & 872,00 \\
\hline
\end{tabular}

Tablica 12. Mann-Whitney U testovi za pretpostavku 6

\begin{tabular}{|l|c|}
\hline & Tolerantna osoba \\
\hline Mann-Whitney U & 407,000 \\
\hline Wilcoxon W & 872,000 \\
\hline $\mathbf{Z}$ &,- 715 \\
\hline $\begin{array}{l}\text { Egz. Sig. } \\
\text { (dvostrani test) }\end{array}$ &, 531 \\
\hline $\begin{array}{l}\text { Egz. Sig. } \\
\text { (jednostrani test) }\end{array}$ &, 266 \\
\hline
\end{tabular}


iskren i topao odnos dosegli visoku razinu tolerancije kao odrasli ljudi danas.

Upravo autoritarni stil roditeljstvo podrazumijeva nadzor nad osjećajima te potiče razvoj agresivnosti, ćudljivosti te nisku razinu tolerancije na frustraciju (Pernar, 2010), a to kasnije u mnogim slučajevima može imati negativne posljedice kako za samu osobu tako i za nju u ulozi roditelja. Upravo je tolerancija (uz solidarnost, empatiju, obzirnost, itd.) jedna od temeljnih moralnih i etičkih vrijednosti za koju se u zadnje vrijeme vrlo često insinuira da gubi bitku sa suvremenim vrijednostima koje se svode na moć i profit (Jukić, 2013) te stoga ovi rezultati mogu biti promatrani kao pozitivan prediktor inkluzivnog društva.

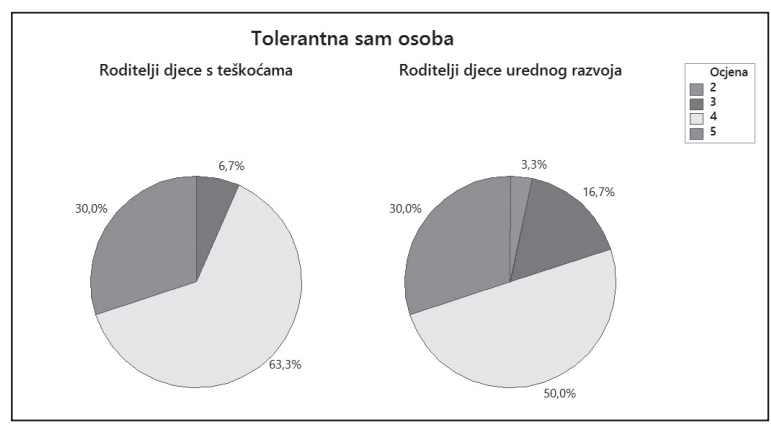

Slika 4. Samoprocjena razine tolerancije roditelja $u$ interakciji s okolinom

\section{Razlike u poimanju važnosti vremena koje roditelji provode sa svojim obiteljima}

Jedna od pretpostavki ovog istraživanja usmjerena je na temu vremena koje roditelji provode $\mathrm{s}$ obitelji, odnosno pretpostavlja se da ne postoje razlike kada je u pitanju vrijeme koje roditelji iz obje skupine žele imati na raspolaganju kako bi ga provodili sa svojim obiteljima. Mann-Whitney U test pokazuje kako nema statistički značajne razlike između skupina ( $U=447,000, z=-, 064)$ te su obje skupine u $80 \%$ slučajeva odgovorile kako im je važno imati vremena za obitelj.

Istraživanja koja su proveli Berc i Kokorić (2012) pokazuju kako majke u odnosu na očeve provode više vremena s djecom, a upravo su majke popunjavale ovaj anketni upitnik pa postoji velika mogućnost da je ta činjenica utjecala na dobiveni rezultat. Današnji suvremeni način života podrazu-
Tablica 13. Rangovi subjektivnih ocjena po skupinama za pretpostavku 7

\begin{tabular}{|l|l|c|c|c|}
\hline & Skupina & $\mathbf{N}$ & $\begin{array}{c}\text { Prosjek } \\
\text { ranga }\end{array}$ & $\begin{array}{c}\text { Suma } \\
\text { ranga }\end{array}$ \\
\hline $\begin{array}{l}\text { Važno imati } \\
\text { vremena za } \\
\text { obitelj }\end{array}$ & $\begin{array}{l}\text { Roditelji djece s } \\
\text { teškoćama }\end{array}$ & 30 & 30,60 & 918,00 \\
\cline { 2 - 5 } & $\begin{array}{l}\text { Roditelji djece } \\
\text { urednog razvoja }\end{array}$ & 30 & 30,40 & 912,00 \\
\hline
\end{tabular}

Tablica 14. Mann-Whitney U testovi za pretpostavku 7

\begin{tabular}{|l|c|}
\hline & Važno imati vremena za obitelj \\
\hline Mann-Whitney U & 447,000 \\
\hline Wilcoxon W & 912,000 \\
\hline Z &,- 064 \\
\hline $\begin{array}{l}\text { Egz. Sig. } \\
\text { (dvostrani test) }\end{array}$ & 1,000 \\
\hline $\begin{array}{l}\text { Egz. Sig. } \\
\text { (jednostrani test) }\end{array}$ &, 500 \\
\hline
\end{tabular}

mijeva modifikaciju obitelji u kontekstu strukture obitelji (otac više nije taj koji jedini financijski doprinosi, majke su zaposlene, stvaraju karijere, paralelno se brinu za obitelj i sl.). Iako to utječe na činjenicu da roditelji provode sve manje kvalitetnog vremena sa svojim obiteljima (Gregor, 2013), odgovori dobiveni u ovom istraživanju upućuju na to da roditelji ipak pridaju veliku važnost vremenu koje provode s obitelji.

\section{Razlike u samoprocjeni posjedovanja pozitivnog stava prema životu između roditelja djece urednog razvoja i roditelja djece $s$ teškoćama}

Mann-Whitney U test je pokazao da ne postoje statistički značajne razlike u samoprocjeni zauzimanja pozitivnog stava prema različitim životnim okolnostima, $U=414,000, z=-, 573$.

Tablica 15. Rangovi subjektivnih ocjena po skupinama za pretpostavku 8

\begin{tabular}{|l|l|c|c|c|}
\hline & Skupina & N & $\begin{array}{c}\text { Prosjek } \\
\text { ranga }\end{array}$ & $\begin{array}{c}\text { Suma } \\
\text { ranga }\end{array}$ \\
\hline $\begin{array}{l}\text { Pozitivan } \\
\text { stav prema } \\
\text { životu }\end{array}$ & $\begin{array}{l}\text { Roditelji djece s } \\
\text { teškoćama }\end{array}$ & 30 & 29,30 & 879,00 \\
\cline { 2 - 5 } & $\begin{array}{l}\text { Roditelji djece } \\
\text { urednog razvoja }\end{array}$ & 30 & 31,70 & 951,00 \\
\hline $\begin{array}{l}\text { Osjećaj kao } \\
\text { žrtva }\end{array}$ & $\begin{array}{l}\text { Roditelji djece s } \\
\text { teškoćama }\end{array}$ & 30 & 32,70 & 981,00 \\
\cline { 2 - 5 } & & 30 & 28,30 & 849,00 \\
\hline
\end{tabular}


Test također ukazuje i na to da nema statistički značajne razlike u doživljaju sebe kao žrtve, $\mathrm{U}=384,000, \mathrm{z}=-1,026$ između ove dvije skupine. Doživljaj roditeljstva kao žrtvovanja se inače javlja kod starijih roditelja koji su zapostavljani od svoje odrasle djece te se isti povezuje s raznim individualnim situacijama (Lacković-Grgin, 2011). To upućuje na nepovezanost „žrtvovanja“ s činjenicom pripadnosti pojedinoj promatranoj skupini te ističe individuu kao takvu zajedno s njenim jedinstvenim reakcijama na situaciju u kojoj se nađe.

Tablica 16. Mann-Whitney U testovi za pretpostavku 8

\begin{tabular}{|l|c|c|}
\hline & $\begin{array}{c}\text { Pozitivan stav } \\
\text { prema životu }\end{array}$ & $\begin{array}{c}\text { Osjećaj kao } \\
\text { žrtva }\end{array}$ \\
\hline Mann-Whitney U & 414,000 & 384,000 \\
\hline Wilcoxon W & 879,000 & 849,000 \\
\hline Z &,- 573 & $-1,026$ \\
\hline $\begin{array}{l}\text { Egz. Sig. } \\
\text { (dvostrani test) }\end{array}$ &, 597 &, 306 \\
\hline $\begin{array}{l}\text { Egz. Sig. } \\
\text { (jednostrani test) }\end{array}$ &, 299 &, 153 \\
\hline
\end{tabular}

\section{Razlike u samoprocjeni životnog zadovoljstva između roditelja djece urednog razvoja i roditelja djece s teškoćama}

Kada se promatra samoprocjena razine osobnog zadovoljstva (koju obuhvaća niz faktora), test pokazuje kako postoji statistički značajna razlika $(\mathrm{U}=308,500, \mathrm{z}=-2,302, \mathrm{p}<0,05)$ između ove dvije skupine. Obrađeni podaci ukazuju na to da $93,3 \%$ roditelja djece urednog razvoja sebe procjenjuje kao gotovo u potpunosti zadovoljnu osobu, dok je to kod roditelja djece s teškoćama slučaj u 56,7\% .

Rezultati ukazuju na to da u ovom segmentu postoji značajna razlika između dvije skupine roditelja. S obzirom na druga istraživanja (Paster i sur., 2009) koja su pokazala da rodite- lji djece s teškoćama svoju ulogu doživljavaju opterećujućom te da im je roditeljska uloga kao takva zahtjevna (Starc, 2014), dobiveni rezultati nisu iznenađujući. Prema tome, objašnjenje pokazane značajne razlike u ovom segmentu je moguće tražiti u prevelikom svakodnevnom opterećenju koje postoji kod roditelja djece s teškoćama.

Tablica 18. Mann-Whitney U testovi za pretpostavku 9

\begin{tabular}{|l|c|c|}
\hline & $\begin{array}{c}\text { Zadovoljstvo } \\
\text { fizičkim } \\
\text { izgledom }\end{array}$ & $\begin{array}{c}\text { Zadovoljna } \\
\text { osoba }\end{array}$ \\
\hline Mann-Whitney U & 363,000 & 308,500 \\
\hline Wilcoxon W & 828,000 & 773,500 \\
\hline $\mathbf{Z}$ & $-1,385$ & $-2,302$ \\
\hline $\begin{array}{l}\text { Egz. Sig. } \\
\text { (dvostrani test) }\end{array}$ &, 170 &, 014 \\
\hline $\begin{array}{l}\text { Egz. Sig. } \\
\text { (jednostrani test) }\end{array}$ &, 085 &, 007 \\
\hline
\end{tabular}

Kada se promatra zadovoljstvo fizičkim izgledom, Mann-Whitney U test pokazuje da nema statistički značajne razlike u razini zadovoljstva između dvije promatrane skupine roditelja, $U=363,000$, $\mathrm{z}=-1,385$.

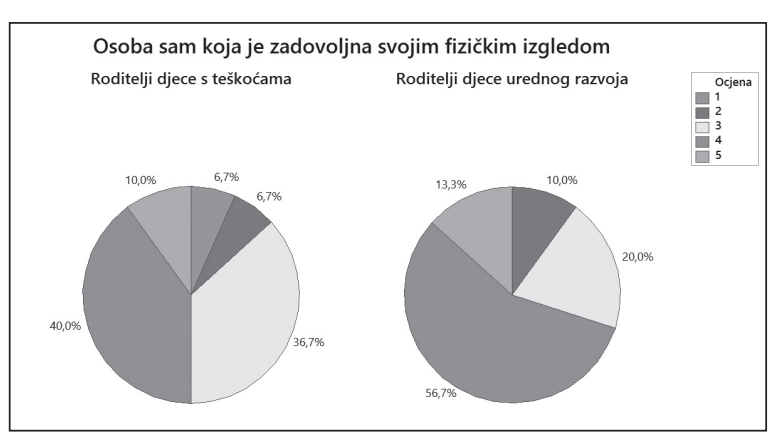

Slika 5. Zadovoljstvo roditelja fizičkim izgledom

Samo $13,3 \%$ roditelja djece urednog razvoja i $10 \%$ roditelja djece $\mathrm{s}$ teškoćama je u potpunosti zadovoljno svojim fizičkim izgledom.

Tablica 17. Rangovi subjektivnih ocjena po skupinama za pretpostavku 9

\begin{tabular}{|l|l|c|c|c|}
\hline & Skupina & N & $\begin{array}{c}\text { Prosjek } \\
\text { ranga }\end{array}$ & $\begin{array}{c}\text { Suma ranga } \\
\text { Zadovoljstvo fizičkim izgledom }\end{array}$ \\
\cline { 2 - 5 } & Roditelji djece s teškoćama & 30 & 27,60 & 828,00 \\
\cline { 2 - 5 } & Roditelji djece urednog razvoja & 30 & 33,40 & 1002,00 \\
\hline \multirow{2}{*}{ Zadovoljna osoba } & Roditelji djece s teškoćama & 30 & 25,78 & 773,50 \\
\cline { 2 - 5 } & Roditelji djece urednog razvoja & 30 & 35,22 & 1056,50 \\
\hline
\end{tabular}




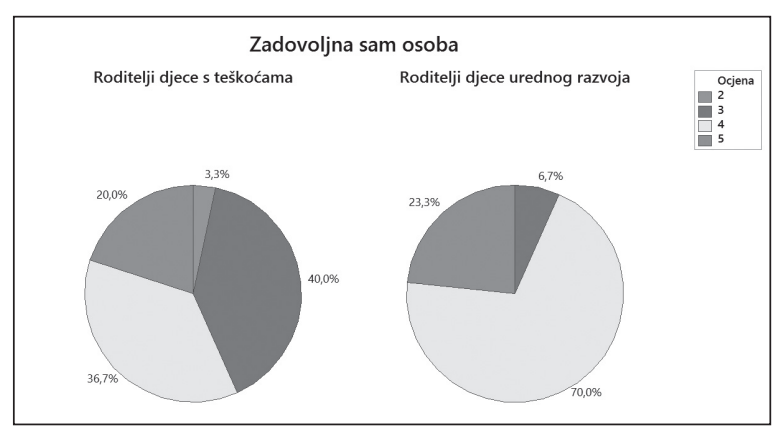

Slika 6. Samoprocjena općeg zadovoljstva roditelja

\section{Razlike u samoprocjeni vlastite uspješnosti između roditelja djece urednog razvoja i roditelja djece s teškoćama}

Iako se pretpostavilo kako ne postoje značajne razlike u samoprocjeni vlastite uspješnosti između roditelja djece urednog razvoja i roditelja djece s teškoćama, Mann-Whitney U test je pokazao suprotno. Test pokazuje kako postoji statistički značajna razlika u samoprocjeni uspješnosti $U=310,000$, $\mathrm{z}=-2,190, \mathrm{p}<0,05 \mathrm{kod}$ ove dvije skupine roditelja. Roditelji djece urednog razvoja se uglavnom ili u potpunosti smatraju uspješnim osobama $(73,3 \%)$, dok roditelji djece s teškoćama samo u $37 \%$ slučajeva procjenjuju sebe uspješnim osobama.

Tablica 19. Rangovi subjektivnih ocjena po skupinama za pretpostavku 10

\begin{tabular}{|l|l|c|c|c|}
\hline & Skupina & N & $\begin{array}{c}\text { Prosjek } \\
\text { ranga }\end{array}$ & $\begin{array}{c}\text { Suma } \\
\text { ranga }\end{array}$ \\
\hline $\begin{array}{l}\text { Uspješna } \\
\text { osoba }\end{array}$ & $\begin{array}{l}\text { Roditelji djece s } \\
\text { teškoćama }\end{array}$ & 30 & 25,83 & 775,00 \\
\cline { 2 - 5 } & $\begin{array}{l}\text { Roditelji djece } \\
\text { urednog razvoja }\end{array}$ & 30 & 35,17 & 1055,00 \\
\hline
\end{tabular}

Dobiveni rezultati koji ukazuju na postojanje značajne statističke razlike u ovom segmentu nisu iznenađujući s obzirom na to da roditelji djece s teškoćama vrlo često koriste različite oblike prava iz socijalne skrbi (produljeni rodiljni dopust radi njege djeteta s teškoćama, skraćeno radno vrijeme i sl.). Te okolnosti ih dovode u situaciju poslovne neaktivnosti pa stoga nisu ni u mogućnosti ostvarivati planirane korake u karijeri.

Moguće je da razlike ne bi bile značajne da su uzorak roditelja s teškoćama činili isključivo zapo-
Tablica 20. Mann-Whitney U testovi za pretpostavku 10

\begin{tabular}{|l|c|}
\hline & Uspješna osoba \\
\hline Mann-Whitney U & 310,000 \\
\hline Wilcoxon W & 775,000 \\
\hline Z & $-2,190$ \\
\hline Egz. Sig. (dvostrani test) &, 028 \\
\hline Egz. Sig. (jednostrani test) &, 014 \\
\hline
\end{tabular}

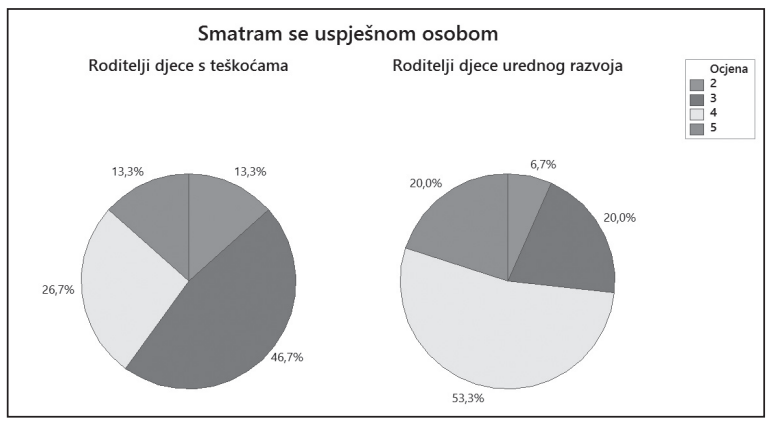

Slika 7. Samoprocjena vlastite uspješnosti roditelja

sleni roditelji. Ipak, kod ovih je rezultata bitno uzeti u obzir i činjenicu kako roditelji djece s razvojnim teškoćama vrlo često doživljavaju neuspjeh te svoje kompetencije u kontekstu roditeljstva nerijetko interpretiraju nerealno negativno (Kralj, 2012). Moguće je kako je upravo nerealna interpretacija doživljaja vlastitog uspjeha ključna podloga za ove rezultate.

\section{ZAKLJUČAK}

Temeljem rezultata provedenog istraživanja može se zaključiti kako ne postoje značajne razlike u samoprocjeni između roditelja djece s teškoćama i roditelja djece urednoga razvoja, a koje su direktno povezane s pripadnošću pojedinoj skupini. Značajna razlika u samoprocjeni je utvrđena samo u dvije od deset postavljenih pretpostavki. Razloge za razlike u razini osobnog zadovoljstva te postignutog uspjeha moguće je objasniti činjenicom da su svi roditelji djece s teškoćama koji su sudjelovali u ovom istraživanju u nepovoljnom položaju zbog toga što ili nisu zaposleni ili jesu zaposleni, ali koriste neki oblik roditeljskog prava. Roditeljstvo djeteta s teškoćama donosi promjene u obiteljskoj dinamici i nerijetko jedan od roditelja zbog stjecaja okolnosti manje ulaže u vlastito obrazovanje i cjeloživotno učenje te općenito u poslovni dio života. Suočavanje s prisilnim odricanjem 
od karijere ili gubitkom posla jednog od roditelja događaj je koji stvara poremećaj u funkcioniranju obitelji kao takve (Britvić, 2010). Ta situacija stavlja u neravnopravan položaj roditelja koji se u njoj nađe te ista za sobom povlači i niz drugih negativnih osjećaja koji djeluju kako na roditelja tako i na cijelu obitelj. Nerijetko se javlja osjećaj manje vrijednosti, nesigurnosti i tjeskobe (Britvić, 2010). Sve to potvrđuje koliko je kod obje skupine roditelja važan doživljaj sebe kao osobe koja doprinosi u obitelji. Koliko su osobni doprinos i napredak bitni za obje skupine roditelja potvrđuju i rezultati koji pokazuju kako roditelji djece s teškoćama i roditelji djece bez teškoća iskazuju veliku sklonost prema stjecanju novih znanja i vještina te smatraju kako bi im ona povećala osobnu razinu zadovoljstva.

Rezultate koji kod obje skupine u jednakom postotku ukazuju na pozitivan stav kada je riječ o suočavanju s različitim izazovnim životnim situacijama, moguće je tumačiti kroz postojanje vlastite osobnosti pojedinca te nizom individualnih događaja koji ga kroz život određuju (Lacković-Grgin, 2011), a ne pripadnosti jednoj od skupina. Svaki pojedinac je jedinstven i sam kreira svoje stavove, utječe na svoje raspoloženje, poimanje okoline te stvara svoja rješenja vezano za okolnosti i situacije u kojima se nađe.
Sve navedeno vodi do zaključka kako ne postoji potreba za prilagodbom komunikacijskog pristupa tijekom edukativnog rada s roditeljima koja bi se temeljila na činjenici pripadnosti jednoj od dvije promatrane skupine, ali provedeno istraživanje upućuje na nužnost pružanja potpore roditeljima općenito. Današnji način života suočava roditelje s brojnim izazovima, a metode koje će oni primijeniti u suočavanju s istima ovise o njima samima. Adekvatan sustav socijalne podrške u kontekstu stručne podrške značajno bi poboljšao kvalitetu života roditeljima djece s teškoćama (Paster,2009), ali treba uzeti u obzir i rezultate ovog istraživanja koji ukazuju na potrebu pružanja socijalne podrške roditeljima općenito, odnosno nevezano na skupinu kojoj pripadaju. U tom kontekstu također treba imati na umu dostupnost informacija kao jednu od najzastupljenijih roditeljskih potreba (Kralj, 2012).

Edukacija, vještine suočavanja i socijalna podrška (Lebedina-Manzoni, Novak, Jeđud, 2006), nameću se kao ključni čimbenici u samoprocjeni. Rezultati ovog istraživanja mogu poslužiti kao podloga za razvoj metodologije pristupa u kontekstu pružanja socijalne podrške za obje skupine roditelja jer jasno ukazuju na „osjetljiva“ područja u kojima su roditelji iskazali nižu razinu samoprocjene. 


\section{LITERATURA}

Abidin, R., R. (1995): Parenting Stress Index. Third Edition. Lutz: Psychological Assessment Resources, Inc.

Ackerman, NW. (1958): The psychodynamics of family life. New York: Publisher Basic book inc.

Antshel, K. M., Joseph, G., R. (2006): Maternal Stress in Nonverbal Learning Disorder:

A Comparison With Reading Disorder, 30-3, $194-205$.

Brazelton, B., Greenspan, S. (2000): The Irreducible Needs Of Children: What Every Child Must Have To Grow, Learn, And Flourish Paperback. New York, Perseus Books.

Berc, G., Blažeka Kokorić, S. (2012): Slobodno vrijeme obitelji kao čimbenik obiteljske kohezivnosti i zadovoljstva obiteljskim životom. Kriminologija \& socijalna integracija: časopis za kriminologiju, penologiju i poremećaje u ponašanju, 20, 2, 15-27.

Britvić, D. (2010): Obitelj i stres. Medicina Fluminensis, 46, 3, 267-272.

Deater-Deckard, K. (2004): Parenting stress. London: Yale University Press.

Čanić, S. (2013): Primjena principa geštalt terapije u coachingu. Klinička psihologija, 6, 1-2, 111-123.

Čudina-Obradović, M., Obradović, J. (2006): Psihologija braka i obitelji. Zagreb: Golden marketing-Tehnička knjiga.

Čudina-Obradović, M., Obradović J. (2003): Potpora roditeljstvu: izazovi i mogućnosti. Revija za socijalnu politiku, $10,1,45-68$.

Field, A. (2013): Discovering statistics using IBM SPSS statistics. London: Sage.

Home, A. (2002): Challenging hidden oppression: Mothers caring for children with disabilities. Critical Social Work, $2,2,88-103$.

Gregor, H. (2013). Theology of Parenting: Is Parenting in Crisis Today?. Biblijski pogledi, 21, 1-2, 115-130.

Igrić, L., Wagner Jakab A., Cvitković, D. (2012): Samoprocjena i procjena ponašanja učenika s teškoćama u redovnoj osnovnoj školi. Hrvatska revija za rehabilitacijska istraživanja, 48, 1, 1-10.

Judge, S. L. (1998): Parental coping strategies and strengths in families of young children with disabilities. Family Relations, 47-3, 263-268.

Jukić, R. (2013): Moralne vrijednosti kao osnova odgoja. Nova prisutnost : časopis za intelektualna i duhovna pitanja, $10,3,401-416$.

Klarin, M.(2006.): Razvoj djece u socijalnom kontekstu. Jastrebarsko: Naklada Slap.

Kralj, T. (2012): Opterećenje i potrebe roditelja male djece s razvojnim poteškoćama. Magistarski rad. Sveučilište u Zagrebu Filozofski fakultet.

Kušević, B. (2009): Licencija za roditeljstvo - buduća realnost ili utopijska projekcija?. Pedagogijska istraživanja, $6,1-2,191-200$.

Lacković-Grgin, K. (2011): Doživljaj i praksa roditeljstva u različitim životnim razdobljima. Društvena istraživanja: časopis za opća društvena pitanja, 20,4, 114.

Leutar Z., Oršulić V. (2015): Povezanost socijalne podrške i nekih aspekata roditeljstva u obiteljima s djecom s teškoćama u razvoju. Revija za socijalnu politiku, 2, 153-176.

Lebedina-Manzoni, M., Novak, T., Jeđud, I. (2006): Doživljaj sebe u obitelji. Kriminologija \& socijalna integracija: časopis za kriminologiju, penologiju i poremećaje u ponašanju, 14,2, 25-36.

Ljubešić, M. (2004): Izazovi odrastanja i roditeljstvo. Nova prisutnost, 2, 2, 325-328.

Ljubešic, M., Šimleša, S. (2016): Early Childhood Inclusion in Croatia. Infants \& Young Children, 29,3, 195-204. 
Ivana Rašan, Željka Car, Jasmina Ivšac Pavliša: Doživljaj samoga sebe i okoline kod roditelja djece urednog razvoja i roditelja djece...

Ljubešić, M., Šimleša, S., Bučar, M. (2015.): Razvoj inkluzivne prakse u dječjim vrtićima. Hrvatska udruga za ranu intervenciju u djetinjstvu (HURID).

Maleš, D. (1993). Škola - roditelji - djeca. Obnovljeni život: časopis za filozofiju i religijske znanosti, 48, 6, 587-593.

Milić Babić, M. (2012): Neke odrednice roditeljskog stresa u obiteljima djece s teškoćama u razvoju. Hrvatska revija za rehabilitacijska istraživanja, 48, 2, 66-75.

Miljković, D., Rijavec, M. (2009): Važnost pozitivnih emocija u odgoju i obrazovanju. Napredak : časopis za pedagogijsku teoriju i praksu, 150, 3-4, 488-506.

Minuchin S. (1974): Families and and family therapy. Cambridge:Harvard Press.

Not, T. (2008.): Mentalna retardacija: definicija, klasifikacija i suvremena podrška osobama s intelektualnim teškoćama, Nova prisutnost, 6, 3, 339-351.

Pap, E. (2007.): Može li vrijeme latencije služiti kao indikator socijalno poželjnog odgovaranja na upitnicima ličnosti? Diplomski rad. Sveučilište u Zagrebu Filozofski fakultet, Odsjek za psihologiju.

Paster, A., Brandwein, D., Walsh, J. (2009): A comparison of coping strategies used by parents of

children with disabilities and parents of children without disabilities. Research in Developmental Disabilities, 30, $1337-1342$.

Pećnik, N. (2008): Suvremeni pogledi na dijete, roditeljstvo i socijalizaciju. Dijete i društvo, 10, 1-2, 99-115.

Pećnik, N. (2013): Kako roditelji i zajednice brinu o djeci najmlađe dobi u Hrvatskoj. Ured UNICEF-a za Hrvatsku.

Pernar, M.(2010): Roditeljstvo. Medicina Fluminensis, 46-3, 255-260.

Perry, A. (2004): A Model of Stress in Families of Children with Developmental Disabilities: Clinical and Research Applications. Journal on developmental disabilities, 11-1, 1-16.

Petani, R., Kristić, K. (2012): Komparativni pristup programima osposobljavanja obitelji i potpori roditeljima, Pedagogijska istraživanja, 9, 1-2, 117-128.

Popčević, K., Ivšac Pavliša, J., Šimleša, S. (2015): Razvojna procjena i podrška djeci s poremećajima iz autističnog spektra. Klinička psihologija, 8, 1, 19-31.

Sarafino, E. P. (2002): Health Psychology. New York: Wiley.

Seligman, R., Darling, R. B. (2007): Ordinary Families, Special Children: A Systems Approach to Childhood Disability. Ney York, The Guilford Press.

Simon, R. W. (1992.): Parental Role Strains, Salience of Parental Identity and Gender Differences in Psychological Distress. Journal of Health and Social Behavior, 33, 25-35.

Smojver-Ažić, S., Martinac-Dorčić, T. (2010): Povezanost osobina ličnosti i nekih karakteristika obiteljskog funkcioniranja sa psihičkim simptomima majki i očeva. Društvena istraživanja, 19, 1-2, 105-106.

Starc, B. (2014): Roditeljstvo u najboljem interesu djeteta i podrška roditeljima najmlađe djece s teškoćama u razvoju. Ured UNICEF-a za Hrvatsku.

Waisbren S. E, Rones M., Read C. Y, Marsden D., Levy H. L. (2004): Brief report: Predictors of parenting stress among parents of children with biochemical genetic disorders. Journal of Pediatric Psychology, 29-7, 565 - 570.

Žic, A., Nikolić, B., Igrić, L. (1997): Utjecaj integrativne gestalt terapije na usvojenost vještina i navika svakodnevnog života. Hrvatska revija za rehabilitacijska istraživanja, 33, 2, 133-142.

\section{Ostalo:}

http://multisklad.ict-aac.hr/

http://www.ict-aac.hr/index.php/hr/ 


\section{PERCEPTION OF ONESELF AND ONE'S ENVIRONMENT AMONG PARENTS WHO HAVE CHILDREN WITH DEVELOPMENTAL DISABILITIES AND PARENTS OF TYPICALLY DEVELOPING CHILDREN}

Abstract: Parenting of children with developmental disabilities brings many challenges and stressful situations that are related to insufficient professional support (Paster, Brandwein, Walsh, 2009). Furthermore, parents of children with developmental disabilities often experience failure, which causes unreal interpretations regarding their role as parents.

Due to the limited initiatives in this research area, the focus of this paper was on comparison of two different groups of parents - parents of children with developmental disabilities and parents who have typically developing children, with the emphasis on their own experience in different life segments. The study included 60 parents, 30 parents of children with developmental disabilities and 30 parents of typically developing children.

A Likert scale was used in the research and respondents specified their level of agreement with a statement on a five-point scale. Since the aim was to determine if there was a difference between the two independent groups of parents, the non-parametric rank-sum test (Mann-Whitney U test) was used. The results showed that there were significant differences between those two groups related to self-competence and their own perception regarding success, in favour of parents with typically developing children. Furthermore, no differences were found between parents who have children with developmental disabilities and parents who have typically developing children in any of the other domains that were observed (e.g. striving for progress, a positive attitude, productivity and achievements).

The obtained results indicate a positive attitude in dealing with various challenging life situations, which could be explained through the existence of one's own personality and a series of individual events that determine an individual through life (LackovićGrgin, 2011), whereas belonging to a particular group does not need to be taken into account.

Keywords: challenging parenthood, children with developmental disabilities, typically developing children, parents of children with developmental disabilities, parents of typically developing children, perception of oneself 